\title{
An Efficiency Wage-Imperfect Information Model of the Phillips Curve
}

\author{
Carl M. Campbell III \\ Department of Economics, Northern Illinois University, DeKalb, IL, USA \\ Email: carlcamp@niu.edu
}

How to cite this paper: Campbell III, C.M (2017) An Efficiency Wage-Imperfect Information Model of the Phillips Curve. Open Journal of Social Sciences, 5, 24-39. https://doi.org/10.4236/jss.2017.52004

Received: December 21, 2016

Accepted: January 22, 2017

Published: January 25, 2017

Copyright ( 2017 by author and Scientific Research Publishing Inc. This work is licensed under the Creative Commons Attribution International License (CC BY 4.0).

http://creativecommons.org/licenses/by/4.0/

\begin{abstract}
This study develops an efficiency wage model in which workers have imperfect information about wages elsewhere. Firms' profit-maximizing behavior results in a Phillips curve relationship. Three types of Phillips curves are derived: a wage-wage Phillips curve, a wage-price Phillips curve, and a priceprice Phillips curve. The wage-wage Phillips curve is a reduced form relationship with the coefficient on lagged wage inflation equaling 1 . To obtain the wage-price and the price-price Phillips curves, stochastic shocks to the growth rate of demand are modeled, yielding expressions over time for wage inflation, price inflation, and unemployment. These expressions are used in a regression of current wage or price inflation on unemployment and lagged price inflation, and it is demonstrated that the coefficient on lagged inflation asymptotically approaches 1 . In addition, the model predicts that real wages are strictly procyclical in response to technology shocks, but can be either procyclical, acyclical, or countercyclical in response to demand shocks. Thus, this study can explain why economists have reached different conclusions about the cyclical behavior of real wages.
\end{abstract}

\section{Keywords}

Phillips Curve, Efficiency Wages, Imperfect Information

\section{Introduction}

The origins of the Phillips curve lie in Phillips' (1958) [1] analysis of British data from 1861-1957, which finds a negative relationship between the unemployment rate and the rate of wage inflation. Samuelson and Solow (1960) [2] extend the Phillips curve to also refer to the relationship between the unemployment rate and the rate of price inflation. Friedman (1968) [3] and Phelps (1968) [4] argue that expected inflation should be included as an independent variable in a Phillips curve, with a predicted coefficient of 1 . With this expectations-augmented 
Phillips curve, the economy is characterized by a natural rate of unemployment, to which it eventually returns following a shock.

In empirical estimation of the Phillips curve, expected inflation is generally proxied by lagged inflation. Researchers find evidence for the expectationsaugmented Phillips curve, as the coefficient on unemployment is generally negative and the sum of coefficients on lagged inflation is generally close to 1 in regressions of wage or price inflation on unemployment and lagged inflation. (See, for example, King and Watson, 1994 [5]; Fuhrer, 1995 [6]; Campbell, 1997 [7]; Staiger, Stock, and Watson, 2001 [8]; Flaschel, Kauermann, and Semmler, 2007 [9]; and Galí, 2011 [10] for empirical evidence for the Phillips curve.) However, while economists find empirical support for the Phillips curve, it is more difficult to provide theoretical justification for it.

This study develops an efficiency wage model in which workers have incomplete information about wages at other firms. The wage and employment decisions of profit-maximizing firms result in a Phillips curve relationship at the aggregate level between inflation (either of wages or prices), unemployment, and lagged inflation. Three Phillips curve specifications are considered: a regression of wage inflation on unemployment and lagged wage inflation (the wage-wage Phillips curve), a regression of wage inflation on unemployment and lagged price inflation (the wage-price Phillips curve), and a regression of price inflation on unemployment and lagged price inflation (the price-price Phillips curve).

The wage-wage Phillips curve is a reduced-form relationship that is derived directly from the profit-maximizing behavior of firms. In this equation, the sum of coefficients on lagged wage inflation equals 1 , and the coefficient on unemployment is negative and depends on just four parameters.

The wage-price Phillips curve and price-price Phillips curve are not reducedform equations. Rather, they are statistical relationships obtained from modeling stochastic shocks to the growth rate of demand. Modeling these shocks yields expressions for wages, prices, and unemployment in each period as functions of these shocks. These expressions are then treated as data in a regression in which the independent variables are unemployment and lagged price inflation and the dependent variable is the current value of either wage or price inflation. The equation $\hat{\boldsymbol{\beta}}=\left(\mathbf{X}^{\prime} \mathbf{X}\right)^{-1} \mathbf{X}^{\prime} \mathbf{y}$ yields expressions for the coefficients on unemployment and lagged price inflation as functions of the model's microeconomic parameters. It is demonstrated that the coefficient on lagged price inflation asymptotically approaches 1 as the sample size increases. However, even when the sample size is small, the coefficient is very close to 1 when reasonable parameter values are chosen.

These Phillips curves are disequilibrium relationships determined from the response of wages, prices, and unemployment to exogenous demand shocks. Over time, these endogenous variables approach their equilibrium values, which means that the economy is characterized by a natural rate of unemployment.

The model also makes predictions about cyclical behavior of real wages, and it is demonstrated that real wages can be procyclical, acyclical, or countercyclical 
in response to shocks to aggregate demand. The framework can also be used to analyze technology shocks, and real wages are strictly procyclical with respect to these shocks. The model's prediction that real wages can be either procyclical or countercyclical can explain why real wages appear to behave differently in different time periods ${ }^{1}$.

\section{Review of Previous Phillips Curve Studies}

Two prominent models of the Phillips curve are the sticky price Phillips curve and the sticky information Phillips curve. The sticky price Phillips curve (also referred to as the New Keynesian Phillips curve) is discussed in Roberts (1995) [12], who shows that a Phillips curve relationship can be derived from the staggered contract models of Taylor $(1979,1980)$ [13] [14] and Calvo (1983) [15] and from the quadratic adjustment cost model of Rotemberg (1982) [16]. Roberts demonstrates that these models all yield the prediction that inflation depends on expectations of future inflation and on the output gap. While the sticky price model is widely used in policy analysis, it is criticized on several grounds. Fuhrer and Moore (1995) [17] find that it cannot explain why inflation is so persistent, and Ball (1994) [18] shows that this model predicts that announced, credible disinflations may cause booms instead of recessions.

Galí and Gertler (1999) [19] develop another variant of the sticky price Phillips curve in which price inflation depends on expectations of future marginal cost. They measure marginal cost by labor's share of national income and demonstrate that their model outperforms a conventional sticky price model in which inflation depends on the output gap. However, while Galí and Gertler show that price inflation depends on the behavior of wages, their study does not analyze the factors that determine wages.

In the sticky information model of Mankiw and Reis (2002) [20], a fraction of firms receives information in each period that enables them to compute optimal prices, while the remaining firms set prices based on out-of-date information. The authors demonstrate that their model explains output and inflation dynamics better than a sticky price model. The present model is similar to Mankiw and Reis' model in that economic fluctuations result from imperfect information. However, it differs from Mankiw and Reis by assuming a different type of imperfect information. In the Mankiw-Reis model, firms have imperfect information about the optimal price of their products and this imperfect information affects their pricing and output decisions. In contrast, the present study assumes that workers have imperfect information about average wages in making decisions related to their effort and on-the-job search and that this imperfect information affects the wage decisions (and hence employment decisions) of firms.

There are reasons to believe that, in explaining economic fluctuations, work-

${ }^{1}$ Campbell (2010) [11] develops a rudimentary version of the model in this study. This previous study derives an equation for the wage-wage Phillips curve, but does not derive the paths of wage inflation, price inflation, and unemployment in response to aggregate demand shocks; does not consider technology shocks; does not derive the wage-wage, wage-price, and price-price Phillips curves in the context of a single model; and does not consider the cyclical behavior of real wages. 
ers' imperfect information about average wages is more important than firms' imperfect information about optimal prices. Optimal prices in Mankiw and Reis' model depend on aggregate prices and aggregate output. Statistics on the price level and GDP are readily available on the internet, so it is not obvious why firms would operate with out-of-date information. On the other hand, workers' behavior regarding effort and quit decisions should be determined by their wages relative to average wages for workers who are employed in a similar narrowly defined occupational group and who have similar qualifications (e.g., age, experience, and education), and this information is not easily obtainable. In fact, when Bewley (1999) [21] interviewed employers about their labor relations, respondents indicated that they thought their workers did not have a very precise idea about the wages offered at other firms.

There are other ways in which this study differs from the sticky price and sticky information models of the Phillips curve. First, this study considers both the labor market and the product market, whereas some previous studies (e.g., Galí and Gertler, 1999 [19]; Mankiw and Reis, 2002 [20]) do not consider the labor market and thus do not consider unemployment. Second, unlike previous Phillips curve models, this study derives expressions for the wage-wage, wageprice, and price-price Phillips curves in the context of a single model. Third, this study derives explicit expressions for the paths of wages, prices, and unemployment, which are endogenously determined as functions of underlying demand shocks to the economy. Because expressions are derived for these variables, this study is able to analyze the cyclical behavior of real wages.

\section{Assumptions}

In deriving the model, the following assumptions are made:

1) Workers' efficiency (e) depends on the ratio of their current wages to their expectations of average wages at other firms and on the unemployment rate, so that

$$
e=e\left[W_{t} / \bar{W}_{t}^{e}, u_{t}\right] \text {, with } e_{W}>0, e_{u}>0, e_{W W}<0 \text {, and } e_{W u}<0,
$$

where $W_{t}$ is a worker's current wage, $\bar{W}_{t}^{e}$ denotes workers' expectations of average wages (to be defined below), and $u_{t}$ is the unemployment rate. Campbell (2006) [22] demonstrates that an expression of this form can be derived from the utility-maximizing behavior of workers, who balance the cost of exerting effort with the benefit of higher effort, as higher effort reduces the probability of dismissal and thus increases expected future income. The effort model of Campbell is based on the shirking model of Shapiro and Stiglitz (1984) [23] and the gift-exchange model of Akerlof $(1982,1984)$ [24] [25]. Other explanations for why efficiency depends positively on wages and unemployment include the labor turnover models of Stiglitz (1974) [26], Schlicht (1978) [27], and Salop (1979) [28] and the adverse selection model of Weiss (1980) [29]. More generally, the function $e\left[W_{t} / \bar{W}_{t}^{e}, u_{t}\right]$ can be viewed as incorporating all of these explanations. 
2) In the short run, workers have incomplete information about current wages at other firms and use information on lagged average wages to help predict the current average wage rate. Note that this assumption means that wages must vary across firms, so that workers cannot infer the average wage from their own wage $^{2}$. The fact that workers use information on lagged average wages to predict current average wages means that their expectations of average wages can be viewed as a mixture of rational and adaptive expectations. Mathematically, it is assumed that $\bar{W}_{t}^{e}$ is given by the equation,

$$
\bar{W}_{t}^{e}=\left(\bar{W}_{t}\right)^{\omega}\left(\tilde{W}_{t}^{L}\right)^{1-\omega}+v_{t},
$$

where $\bar{W}_{t}$ is the actual average wage, $\tilde{W}_{t}^{L}$ represents workers' expectations of current average wages based on their information on lagged wages, $\omega$ measures the degree to which expectations are unbiased, and $v_{t}$ is a random error term. This assumption is supported the findings of previous studies. Roberts (1998) [30] shows that survey forecasts of inflation can be explained by a model in which part of the population has rational expectations and the rest have adaptive expectations. Pfajfar and Santoro (2010) [31] examine a cross section of individuals' inflation forecasts, and they find that some individuals have rational expectations and that some form their expectations adaptively, while the expectations of others are based on adaptive learning and sticky information. Levine et al. (2012) [32] develop a DSGE model both under the assumption that all firms and households have rational expectations and the assumption that a proportion of households and firms have rational expectations and the rest have adaptive expectations. They find that, "All behavioural models [i.e., models with mixed rational and adaptive expectations] 'decisively', in fact very decisively, dominate the purely rational models with very large LL [log likelihood] differences of around 20."

Campbell (2014) [33] provides theoretical support for the assumption of mixed rational and adaptive expectations. A model is developed in which it is costly for agents both to form incorrect expectations of average wages and to acquire information that would yield an unbiased estimate of the average wage. It is demonstrated that cost minimization implies that wage expectations are a mixture of rational and adaptive expectations, with the value of $\omega$ and the weights on each lag in the adaptive component determined by the model's microeconomic parameters.

3) Firms produce output $(Q)$ with the Cobb-Douglas production function,

$$
Q_{t}=A_{t}^{\phi} L_{t}^{\phi} K_{0}^{1-\phi} e\left[W_{t} / \bar{W}_{t}^{e}, u_{t}\right]^{\phi},
$$

in which $L$ represents labor input, $A$ represents technology (assumed to be exogenous), and $K$ is the capital stock (assumed to be fixed at $K_{0}$ ).

4) Each firm faces a downward-sloping demand curve in the product market of the following form:

${ }^{2}$ For example, it could be assumed that firms make random errors in setting wages, but that the profit-maximizing wage is set on average. These errors could be due to firms' lack of perfect information about the level of product demand or about the parameters in their profit functions. 


$$
Q_{t}^{D}=Y_{t}\left(\frac{P_{t}}{\bar{P}_{t}}\right)^{-\gamma},
$$

where $Y$ is real aggregate demand, $P$ is the firm's price, $\bar{P}$ is the aggregate price level, and $\gamma$ is the price elasticity of demand. Accordingly, the firm's price and total revenue can be expressed as

$$
P_{t}=Y_{t}^{\frac{1}{\gamma}} Q_{t}^{-\frac{1}{\gamma}} \bar{P}_{t}
$$

and

$$
P_{t} Q_{t}=Y_{t}^{\frac{1}{\gamma}} Q_{t}^{\frac{\gamma-1}{\gamma}} \bar{P}_{t}
$$

It is assumed that real aggregate demand is determined from a constant velocity specification, so that $Y_{t}=M_{t} / \bar{P}_{t}$. However, demand shocks have similar effects if it is assumed that aggregate demand is determined from an IS-LM framework ${ }^{3}$.

5) Labor supply is inelastic and equals $N$ times the number of firms. Parameters are chosen so that there is excess supply of labor. As discussed in Campbell (2008) [35], assuming a positive relationship between efficiency and wages does not guarantee that there will be excess supply of labor. Whether a firm operates on its labor supply curve or to the left of its labor supply curve (i.e., pays an efficiency wage) depends on the elasticity of output with respect to the wage, calculated at the market-clearing wage. Since parameters are chosen so that firms maximize profits by paying efficiency wages, wages $(W)$ and employment $(L)$ are determined by differentiating the profit function with respect to both $W$ and $L$.

Given the model's assumptions, profits in period $t$ (net of capital costs) can be expressed as

$$
\Pi=Y_{t}^{\frac{1}{\gamma}}\left[A_{t}^{\phi} L_{t}^{\phi} K_{0}^{1-\phi} e\left[W_{t} / \bar{W}_{t}^{e}, u_{t}\right]^{\phi}\right]^{\frac{\gamma-1}{\gamma}} \bar{P}_{t}-W_{t} L_{t} .
$$

\section{Basic Model}

The profits of the typical firm are given by Equation (1). Differentiating this equation with respect to $L_{t}$ and setting the derivative equal to 0 yields

$$
\frac{\mathrm{d} \Pi}{\mathrm{d} L_{t}}=0=\frac{\phi(\gamma-1)}{\gamma} Y_{t}^{\frac{1}{\gamma}} A_{t}^{\frac{\phi(\gamma-1)}{\gamma}} L_{t}^{\frac{\phi(\gamma-1)}{\gamma}-1} K_{0}^{\frac{(1-\phi)(\gamma-1)}{\gamma}} e\left[W_{t} / \bar{W}_{t}^{e}, u_{t}\right]^{\frac{\phi(\gamma-1)}{\gamma}} \bar{P}_{t}-W_{t},
$$

so that

$$
\begin{aligned}
L_{t}= & W_{t}^{\frac{\gamma}{\phi(\gamma-1)-\gamma}}\left(\frac{\gamma}{\varphi(\gamma-1)}\right)^{\frac{\gamma}{\phi(\gamma-1)-\gamma}} Y_{t}^{-\frac{1}{\phi(\gamma-1)-\gamma}} \\
& \times A_{t}^{-\frac{\phi(\gamma-1)}{\phi(\gamma-1)-\gamma}} K_{0}^{-\frac{(1-\phi)(\gamma-1)}{\phi(\gamma-1)-\gamma}} e\left[W_{t} / \bar{W}_{t}^{e}, u_{t}\right]^{-\frac{\phi(\gamma-1)}{\phi(\gamma-1)-\gamma}} \bar{P}_{t}^{-\frac{\gamma}{\phi(\gamma-1)-\gamma}} .
\end{aligned}
$$

The other first-order condition is

${ }^{3}$ For example, Campbell (2009) [34] develops an AD-AS model in which aggregate demand is determined from an IS-LM specification, and the predictions of the IS-LM specification are similar to what would be obtained with a constant velocity specification. 


$$
\frac{\mathrm{d} \Pi}{\mathrm{d} W_{t}}=0=\phi \frac{\gamma-1}{\gamma} Y_{t}^{\frac{1}{\gamma}} A_{t}^{\frac{\phi(\gamma-1)}{\gamma}} L_{t}^{\frac{\phi(\gamma-1)}{\gamma}} K_{0}^{\frac{(1-\phi)(\gamma-1)}{\gamma}} e[\cdot]^{\frac{\phi(\gamma-1)}{\gamma}-1} e_{W}[\cdot] \frac{1}{\bar{W}_{t}^{e}} \bar{P}_{t}-L_{t} .
$$

If (2) is substituted into (3), the following condition, which is analogous to the Solow (1979) [36] condition, is obtained:

$$
W_{t} e\left[W_{t} / \bar{W}_{t}^{e}, u_{t}\right]^{-1} e_{W}\left[W_{t} / \bar{W}_{t}^{e}, u_{t}\right] \frac{1}{\bar{W}_{t}^{e}}=1 .
$$

Totally differentiating Equation (4) and dividing it by the original equation yields

$$
\begin{aligned}
0 & =\left[1-e^{-1} e_{W} \frac{W_{t}}{\bar{W}_{t}^{e}}+\frac{e_{W W}}{e_{W}} \frac{W_{t}}{\bar{W}_{t}^{e}}\right] \hat{W}_{t} \\
& +\left[-1+e^{-1} e_{W} \frac{W_{t}}{\bar{W}_{t}^{e}}-\frac{e_{W W}}{e_{W}} \frac{W_{t}}{\bar{W}_{t}^{e}}\right] \hat{\bar{W}}_{t}^{e} \\
& +\left[\frac{e_{W u}}{e_{W}}-e^{-1} e_{u}\right] d u_{t},
\end{aligned}
$$

where $\hat{W}_{t}=d W_{t} / W_{t}$ and $\hat{\bar{W}}_{t}^{e}=d \bar{W}_{t}^{e} / \bar{W}_{t}^{e}$. The above equation can be viewed as representing the relationship between percentage deviations in $W_{t}$, percentage deviations in $\bar{W}_{t}^{e}$, and percentage-point deviations in $u_{t}$ from their steady-state values. (Thus, $d u_{t}=u_{t}-u^{*}$, where $u^{*}$ is the natural rate.) The above equation can be further simplified by substituting $\left(W_{t} / \bar{W}_{t}^{e}\right)=e e_{W}^{-1}$ (from Equation (4)), yielding

$$
\hat{W}_{t}=\hat{\bar{W}}_{t}^{e}+\left[\frac{e_{u} e_{W}^{2}}{e^{2} e_{W W}}-\frac{e_{W u} e_{W}}{e e_{W W}}\right] d u_{t} .
$$

If small deviations of $W, \bar{W}^{e}$, and $u$ from their initial equilibrium values are considered, the coefficient on $d u_{t}$ can be treated as a constant, with this constant determined by the initial equilibrium values of $e, e_{W}, e_{u}, e_{W W}$, and $e_{W u}$. The fact that $W=\bar{W}^{e}$ in equilibrium means that (from Equation (4)) $e=e_{W}$. This substitution allows (5) to be expressed as

$$
\hat{W}_{t}=\hat{\bar{W}}_{t}^{e}+\frac{e_{u}-e_{W u}}{e_{W W}} d u_{t} .
$$

The unemployment rate is given by the equation,

$$
u_{t}=\frac{N-L_{t}}{N} \text {. }
$$

Letting $s_{L}=L^{*} / N$ (where $L^{*}$ is the equilibrium value of $L$ ), $d u_{t}$ can be approximated by

$$
d u_{t}=\frac{-d L_{t}}{N}=\frac{-d L_{t}}{\frac{L_{t}^{*}}{S_{L}}} \approx-S_{L} \hat{L}_{t} .
$$

Appendix A (note: all of the appendices are available on-line at http://www.niu.edu/econ/about/directory/faculty/campbell/phillips-paper-appe ndix.pdf) demonstrates that expressing (2) as deviations from steady-state val- 
ues, substituting the resulting expression into (7), aggregating across firms, and substituting (7) into (6) yields

$$
\hat{\bar{W}}_{t}=\frac{e_{W W}}{e_{W W}-s_{L}\left(e_{u}-e_{W u}\right)} \hat{\bar{W}}_{t}^{e}-\frac{s_{L}\left(e_{u}-e_{W u}\right)}{e_{W W}-s_{L}\left(e_{u}-e_{W u}\right)} \hat{M}_{t},
$$

where $\hat{\bar{W}}_{t}$ represents the average wage. Appendix A also derives the following expressions for unemployment and the price level:

$$
d u_{t}=-s_{L}\left(\hat{M}_{t}-\hat{\bar{W}}_{t}\right)
$$

and

$$
\hat{\overline{P_{t}}}=\left[1-\phi+\phi e^{-1} e_{u} s_{L}\right] \hat{M}_{t}-\phi \hat{A}_{t}-\phi e^{-1} e_{u} s_{L} \hat{\bar{W}}_{t}+\phi \hat{\bar{W}_{t}^{e}} .
$$

\section{The Wage-Wage Phillips Curve}

This section derives an equation for the wage-wage Phillips curve. From the second assumption, workers' expectations of average wages are a mixture of rational and adaptive expectations. In specifying a functional form for $\bar{W}_{t}^{e}$, it is assumed that the adaptive component of workers' wage expectations $\left(\tilde{W}_{t}^{L}\right)$ depends on lagged wages and on a geometric weighted average of wage inflation in previous periods. In particular, $\bar{W}_{t}^{e}$ is defined as,

$$
\bar{W}_{t}^{e}=\bar{W}_{t}^{\omega}\left[\bar{W}_{t-1}\left(\frac{\bar{W}_{t-1}}{\bar{W}_{t-2}}\right)^{\lambda_{1}}\left(\frac{\bar{W}_{t-2}}{\bar{W}_{t-3}}\right)^{\lambda_{2}} \cdots\left(\frac{\bar{W}_{t-T}}{\bar{W}_{t-T-1}}\right)^{\lambda_{T}}\right]^{1-\omega} \text { with } \lambda_{1}+\lambda_{2}+\cdots+\lambda_{T}=1 .
$$

In terms of percentage deviations, the above equation can be expressed as,

$$
\begin{aligned}
\hat{\bar{W}}_{t}^{e}=\omega \hat{\bar{W}}_{t}+(1-\omega) & \\
\quad & {\left[\left(1+\lambda_{1}\right) \hat{\bar{W}}_{t-1}+\left(\lambda_{2}-\lambda_{1}\right) \hat{\bar{W}}_{t-2}+\cdots+\left(\lambda_{T}-\lambda_{T-1}\right) \hat{\bar{W}}_{t-T}-\lambda_{T} \hat{\bar{W}}_{t-T-1}\right] . }
\end{aligned}
$$

Substituting (11) into (6) and aggregating across firms yields the following equation for aggregate wage inflation:

$$
\begin{aligned}
\left(\hat{\bar{W}}_{t}-\hat{\bar{W}}_{t-1}\right)= & \frac{e_{u}-e_{W u}}{(1-\omega) e_{W W}} d u_{t}+\lambda_{1}\left(\hat{\bar{W}}_{t-1}-\hat{\bar{W}}_{t-2}\right) \\
& +\lambda_{2}\left(\hat{\bar{W}}_{t-2}-\hat{\bar{W}}_{t-3}\right)+\cdots+\lambda_{T}\left(\hat{\bar{W}}_{t-T}-\hat{\bar{W}}_{t-T-1}\right) .
\end{aligned}
$$

Equation (12) is a reduced-form relationship between current wage inflation, unemployment, and a weighted average of lagged wage inflation (with the weights summing to 1 ), and thus is a reduced-form equation for the wage-wage Phillips curve $e^{4}$. The coefficient on the unemployment rate is negative and depends on just four parameters.

${ }^{4}$ Since $\hat{\bar{W}}_{t}, \hat{\bar{W}}_{t-1}$, and $\hat{\bar{W}}_{t-2}$ are the percentage differences in wages from their initial values, the difference between $\hat{\bar{W}}_{t}$ and $\hat{\bar{W}}_{t-1}$ is the percentage change in wages between period $t-1$ and period $t$, and the difference between $\hat{\bar{W}}_{t-1}$ and $\hat{\bar{W}}_{t-2}$ is the percentage change in wages between period $t-2$ and period $t-1$. 


\section{The Wage-Price Phillips Curve and Price-Price Phillips Curve}

Section 5 derives a reduced-form equation for the wage-wage Phillips curve. However, Phillips curves are generally estimated by regressing either wage inflation or price inflation on unemployment and lagged price inflation. For the wage-price Phillips curve and the price-price Phillips curve, the model does not yield reduced-form coefficients on unemployment or lagged price inflation. To obtain coefficients for these versions of the Phillips curve, a different approach is taken. Stochastic shocks to the growth rate of demand are modeled, yielding expressions for wage inflation, price inflation, and unemployment as functions of the underlying shocks. These expressions are then treated as data in regressions in which unemployment and lagged price inflation are the independent variables and current wage or price inflation is the dependent variable. From these regressions, expressions are obtained for the coefficients on unemployment and lagged inflation as functions of the model's microeconomic parameters and the number of time periods in the sample $(T)$. It is demonstrated that as $T \rightarrow \infty$, the coefficient on lagged inflation approaches 1 in both the wage-price and the price-price Phillips curves. However, even if the sample size is small, the coefficients on lagged inflation are very close to 1 with reasonable parameter values.

In modeling these shocks, it is assumed that $\hat{\bar{W}}_{t}^{e}$ is given by (11), with $\lambda_{1}=1$ and $\lambda_{i}=0$ for $i \geq 2$. (The assumption that $\lambda_{1}=1$ and $\lambda_{i}=0$ for $i \geq 2$ is made to make the model mathematically tractable.) Then, substituting (11) into (8) yields

$$
\begin{aligned}
\hat{\bar{W}}_{t} & =\frac{e_{W W}}{e_{W W}-s_{L}\left(e_{u}-e_{W u}\right)}\left[\omega \hat{\bar{W}}_{t}+2(1-\omega) \hat{\bar{W}}_{t-1}-(1-\omega) \hat{\bar{W}}_{t-2}\right] \\
& -\frac{s_{L}\left(e_{u}-e_{W u}\right)}{e_{W W}-s_{L}\left(e_{u}-e_{W u}\right)} \hat{M}_{t},
\end{aligned}
$$

which can be expressed as

$$
\hat{\bar{W}}_{t}-2 a \hat{\bar{W}}_{t-1}+a \hat{\bar{W}}_{t-2}=(1-a) \hat{M}_{t},
$$

where

$$
a=\frac{(1-\omega) e_{W W}}{(1-\omega) e_{W W}-s_{L}\left(e_{u}-e_{W u}\right)}<1 .
$$

Equation (14) is a second-order difference equation, and its solution yields an expression for wages in each period as a function of current and lagged values of demand. This equation is used to model the effect of a series of stochastic shocks to the growth rate of demand. In particular, it is assumed that the growth rate of demand is 0 for $t \leq 0$, and then can be expressed as $\hat{M}_{t}-\hat{M}_{t-1}=\hat{M}_{t-1}-\hat{M}_{t-2}+\varepsilon_{t}$ for $t \geq 1$, where $\varepsilon_{t}$ is a random error with a mean of 0 . Appendix B derives the following solutions for wage inflation, price inflation, and unemployment:

$$
\hat{\bar{W}}_{t}-\hat{\bar{W}}_{t-1}=\sum_{k=1}^{t} \varepsilon_{k}\left[1-\rho^{t-k+1} \cos [\psi(t-k+1)]\right],
$$




$$
\hat{\bar{P}}_{t}-\hat{\bar{P}}_{t-1}=\sum_{k=1}^{t} \varepsilon_{k}\left[1-\phi\left(\left(\omega-e^{-1} e_{u} s_{L}\right) \rho^{2}+1-\omega\right) \rho^{t-k-1} \cos [\psi(t-k+1)]\right]
$$

and

$$
d u_{t}=-\frac{s_{L}}{\sqrt{1-\rho^{2}}} \sum_{k=1}^{t} \varepsilon_{k} \rho^{t-k+2} \sin [\psi(t-k+1)],
$$

where $\rho=\sqrt{a}$ and $\psi=\arccos \sqrt{a}$.

Consider first the wage-price Phillips curve. To obtain predicted coefficients for this relationship, the above expressions for wage inflation, unemployment, and lagged price inflation are used as data in the regression,

$$
\left(\hat{\bar{W}}_{t}-\hat{\bar{W}}_{t-1}\right)=\hat{\beta}_{1} d u_{t}+\hat{\beta}_{2}\left(\hat{\bar{P}}_{t-1}-\hat{\bar{P}}_{t-2}\right)+\varepsilon_{t} \text {. }
$$

It is assumed that the data start in period $t_{0}$ and end in period $T$. Letting $\hat{\boldsymbol{\beta}}$ represent a vector of the estimated $\beta$ s, values for $\hat{\beta}_{1}$ and $\hat{\beta}_{2}$ can be obtained from the equation $\hat{\boldsymbol{\beta}}=\left(\mathbf{X}^{\prime} \mathbf{X}\right)^{-1} \mathbf{X}^{\prime} \mathbf{y}$, where

$$
\mathbf{y}=\left[\begin{array}{c}
\hat{\bar{W}}_{t_{0}}-\hat{\bar{W}}_{t_{0}-1} \\
\hat{\bar{W}}_{t_{0}+1}-\hat{\bar{W}}_{t_{0}} \\
\vdots \\
\hat{\bar{W}}_{T}-\hat{\bar{W}}_{T-1}
\end{array}\right] \text { and } \mathbf{X}=\left[\begin{array}{cc}
d u_{t_{0}} & \hat{\bar{P}}_{t_{0}-1}-\hat{\bar{P}}_{t_{0}-2} \\
d u_{t_{0}+1} & \hat{\bar{P}}_{t_{0}}-\hat{\bar{P}}_{t_{0}-1} \\
\vdots & \vdots \\
d u_{T} & \hat{\bar{P}}_{T-1}-\hat{\bar{P}}_{T-2}
\end{array}\right] \text {. }
$$

Appendix C demonstrates that as $T \rightarrow \infty$, the asymptotic values of $\hat{\beta}_{1}$ and $\hat{\beta}_{2}$ are

$$
\lim _{T \rightarrow \infty} \hat{\beta}_{1}=\frac{e_{u}-e_{W u}}{(1-\omega) e_{W W}}+3(1-a) \frac{a-\phi\left(\left(\omega-e^{-1} e_{u} s_{L}\right) a+1-\omega\right)}{s_{L}(1+a)}
$$

and

$$
\lim _{T \rightarrow \infty} \hat{\beta}_{2}=1
$$

The asymptotic coefficient on unemployment $\left(\hat{\beta}_{1}\right)$ equals the coefficient on unemployment in the wage-wage Phillips curve plus an additional term. It can be demonstrated that this additional term is negative if real wages are procyclical and is positive if real wages are countercyclical. (The equation for real wages is reported in Section 8.) Thus, if real wages are procyclical (countercyclical), the coefficient on unemployment is larger (smaller) in absolute value in the wage-price Phillips curve than in the wage-wage Phillips curve. In addition, the coefficient on lagged inflation $\left(\hat{\beta}_{2}\right)$ asymptotically approaches 1 . While $\hat{\beta}_{2}$ exactly equals 1 only in the asymptotic case, it is close to 1 with reasonable parameter values, even when the number of observations is small. For example, when there are only 10 observations, $\hat{\beta}_{2}=1.00033$ with the baseline parameters from the micro-based efficiency function in Campbell (2008) [35].

Now consider the price-price Phillips curve. This relationship can be expressed as,

$$
\left(\hat{\bar{P}}_{t}-\hat{\bar{P}}_{t-1}\right)=\hat{\beta}_{1} d u_{t}+\hat{\beta}_{2}\left(\hat{\bar{P}}_{t-1}-\hat{\bar{P}}_{t-2}\right)+\varepsilon_{t} \text {. }
$$


Given the paths of unemployment and price inflation in (15b) and (15c), Appendix $\mathrm{C}$ demonstrates that the asymptotic coefficients are

$$
\begin{aligned}
\lim _{T \rightarrow \infty} \hat{\beta}_{1} & =\frac{e_{u}-e_{W u}}{(1-\omega) e_{W W}} \\
& -\frac{\left(1-3 \rho^{2}\right)\left(1-\rho^{2}\right)\left[\rho^{2}-\phi\left(\left(\omega-e^{-1} e_{u} s_{L}\right) \rho^{2}+1-\omega\right)\right]}{s_{L} \rho^{2}\left(1+\rho^{2}\right)},
\end{aligned}
$$

and

$$
\lim _{T \rightarrow \infty} \hat{\beta}_{2}=1 .
$$

For the price-price Phillips curve, the coefficient on unemployment equals the coefficient on unemployment in the wage-wage Phillips curve plus a term that is positive (negative) if real wages are procyclical (countercyclical). As in the case of the wage-price Phillips curve, the coefficient on lagged inflation asymptotically approaches 1 and is close to 1 even when the number of observations is small. For example, when there are 10 observations, $\hat{\beta}_{2}=0.999105$ with the baseline parameters in Campbell (2008) [35].

From Equations (15a), (15b), and (15c), the long-run response of wage inflation, price inflation, and unemployment to aggregate demand shocks can be calculated. The long-run effect of aggregate demand shocks (i.e., shocks to $\varepsilon$ ) is to raise wages and prices by the same amount as the shock. On the other hand, aggregate demand shocks have no long-run effect on unemployment. In addition, it can be demonstrated that technology shocks have no long-run effect on unemployment. Thus, the economy is characterized by a natural rate of unemployment.

\section{Technology Shocks}

Under the assumption that demand is given by the constant velocity specification, $\hat{Y}_{t}=\hat{M}_{t}-\hat{\bar{P}}_{t}$, shocks to technology $(A)$ have no effect on nominal wages and no effect on employment and unemployment. Given this specification for demand, (14) shows that the only determinant of nominal wages is nominal demand. In addition, (A3) shows that employment depends only on nominal demand and nominal wages. Thus, if nominal demand is held constant, technology shocks would have no effect on either wages or employment. The reason why technology does not affect wages or employment is that, with a constant velocity specification, the direct effect of a rise in technology on labor demand is exactly offset by the effect of a decline in prices on labor demand (since an improvement in technology reduces prices). While technology shocks have no effect on wages or employment, (10) shows that positive technology shocks reduce prices and thus raise real wages.

The prediction that technology shocks reduce prices but do not affect employment and nominal wages is consistent with the findings of Liu and Phaneuf (2007) [37]. Using a structural vector autoregression model, they find that a positive technology shock may either raise or lower per capita hours worked, de- 
pending on the specification of the model (i.e., whether hours are expressed in terms of log-levels or log-differences). They also find that a positive technology shock slightly lowers nominal wage inflation, but that the effect is not significantly different from 0 . Their results also indicate that technology shocks significantly reduce price inflation and significantly increase real wages.

If it is assumed that the economy experiences a combination of demand shocks and technology shocks, the coefficients in the wage-price and price-price Phillips curves will be different from the values predicted by (16) and (17), since these predicted coefficients are derived from modeling a series of demand shocks. On the other hand, the coefficients in a wage-wage Phillips curve will be the same as the values predicted by (12), since (12) is a reduced-form relationship.

\section{The Cyclical Behavior of Real Wages}

This section analyzes the model's predictions concerning the cyclical behavior of real wages. When the economy experiences demand shocks, the behavior of real wages is ambiguous. Appendix B shows that, in response to demand shocks, real wages and unemployment are given by the equations,

$$
\hat{\bar{W}}_{t}-\hat{\bar{P}}_{t}=\frac{\phi\left(\omega-e^{-1} e_{u} s_{L}\right) \rho^{2}+\phi(1-\omega)-\rho^{2}}{\sqrt{1-\rho^{2}}} \sum_{k=1}^{t} \varepsilon_{k} \rho^{t-k} \sin [\psi(t-k+1)],
$$

and

$$
d u_{t}=-\frac{s_{L} \rho^{2}}{\sqrt{1-\rho^{2}}} \sum_{k=1}^{t} \varepsilon_{k} \rho^{t-k} \sin [\psi(t-k+1)] .
$$

The coefficient on $\sum \varepsilon_{k} \rho^{t-k} \sin [\psi(t-k+1)]$ is strictly negative in the equation for unemployment. However, the coefficient on this term in the real wage equation is theoretically ambiguous. Thus, real wages can be either procyclical, acyclical, or countercyclical in response to aggregate demand shocks. In response to technology shocks, real wages are unambiguously procyclical, since positive (negative) technology shocks decrease (increase) prices, but do not affect nominal wages.

Since real wages can be either procyclical or countercyclical in response to demand shocks, the overall cyclical behavior of real wages is theoretically ambiguous. The fact that real wages can be either procyclical or countercyclical can explain why the cyclical behavior of real wages has appeared to differ across time periods. For example, Huang, Liu, and Phaneuf (2004) [38] discuss evidence from previous studies that find that real wages were countercyclical in the interwar period but have been procyclical since the end of World War II.

\section{Conclusions}

This study develops a model of wage setting in which firms pay efficiency wages and workers have imperfect information about average wages. Given these assumptions, it is demonstrated that the profit-maximizing behavior of firms 
yields a downward-sloping Phillips curve. A reduced-form equation for the wage-wage Phillips curve is derived directly from the profit-maximization problem of firms. The wage-price and price-price Phillips curves are obtained by modeling a series of stochastic shocks to demand, calculating expressions for wages, prices, and unemployment, and treating these expressions as data in a regression of wage or price inflation on unemployment and lagged price inflation. In such a regression, the coefficient on lagged inflation asymptotically approaches 1 , and it is very close to 1 even when the sample size is small.

The results of this study suggest that more research should be conducted on the wage-wage Phillips curve. In almost all previous Phillips curve research, the right-hand side variable is expected price inflation, rather than expected wage inflation. However, in the model developed in this study, the wage-wage Phillips curve can be derived from profit-maximizing behavior, so in this model it is the most natural specification of inflation dynamics. While expected price inflation is the independent variable in the vast majority of Phillips curve studies, there is some precedent for a wage-wage specification. In Phelps' (1968) [4] seminal paper, the right-hand side variable is expected wage inflation, resulting in a wagewage Phillips curve. In addition, Perry (1978) [39] regresses average hourly earnings $(A H E)$ on the inverse of the unemployment rate and on lagged values of either $A H E$, the consumer price index ( $C P I)$, or the private nonfarm GDP deflator $(G D P D)$. When the equations are estimated over the longest sample period (1954-1977), the regression with lagged $A H E$ has the lowest standard error, the Durbin-Watson statistic that is closest to 2, and the sum of coefficients on lagged inflation that is closest to 1.0. An additional advantage of a wage-wage specification is that there is no need to control for technology shocks, as discussed in Section 7. Even if the wage-wage Phillips curve is the most natural specification, the model shows why researchers will still find evidence for the wage-price and the price-price Phillips curves.

This study predicts how microeconomic parameters determine the slope of the Phillips curve. The wage-wage Phillips curve depends on the degree of rational expectations, the derivative of efficiency with respect to unemployment, the second derivative of efficiency with respect to the wage, and the cross derivative of efficiency with respect to wages and unemployment. The wage-price and the price-price Phillips curves depend on these parameters and also on the cyclical behavior of real wages. Thus, the model can be used to predict how changes in various parameters would affect the slope of the Phillips curve. For example, if expectations become more rational as information becomes more available, then the Phillips curve will become steeper. Also, if efficiency becomes more (less) responsive to unemployment (perhaps because of demographical changes), the result will be a steepening (flattening) of the Phillips curve.

The model also makes predictions about the cyclical behavior of real wages. In response to productivity shocks, real wages are strictly procyclical. However, when economic fluctuations result from shocks to aggregate demand, the model predicts that real wages can be either procyclical, acyclical, or countercyclical, so 
the overall cyclical behavior of real wages is theoretically ambiguous. Thus, this study can explain why real wages appear to behave differently in different time periods.

\section{References}

[1] Phillips, A.W. (1958) The Relationship between Unemployment and the Rate of Change of Money Wage Rates in the United Kingdom, 1861-1957. Economica, 25, 283-299.

[2] Samuelson, P.A. and Solow, R.M. (1960) Analytical Aspects of Anti-Inflation Policy. American Economic Review, 50, 177-194.

[3] Friedman, M. (1968) The Role of Monetary Policy. American Economic Review, 58, $1-17$.

[4] Phelps, E.S. (1968) Money-Wage Dynamics and Labor-Market Equilibrium. Journal of Political Economy, 76, 678-711. https://doi.org/10.1086/259438

[5] King, R.G. and Watson, M.W. (1994) The Post-War US Phillips Curve: A Revisionist Econometric History. Carnegie-Rochester Conference Series on Public Policy, 41, 157-219. https://doi.org/10.1016/0167-2231(94)00018-2

[6] Fuhrer, J.C. (1995) The Phillips Curve is Alive and Well. New England Economic Review, March/April 1995, 41-56.

[7] Campbell, C.M. (1997) The Variation in Wage Rigidity by Occupation and Union Status. Oxford Bulletin of Economics and Statistics, 59, 133-147. https://doi.org/10.1111/1468-0084.00053

[8] Staiger, D., Stock, J.H. and Watson, M.W. (1997) The NAIRU, Unemployment and Monetary Policy. Journal of Economic Perspectives, 11, 33-49. https://doi.org/10.1257/jep.11.1.33

[9] Flaschel, P., Kauermann, G. and Semmler, W. (2007) Testing Wage and Price Phillips Curves for the United States. Metroeconomica, 58, 550-581. https://doi.org/10.1111/j.1467-999X.2007.00283.x

[10] Galí, J. (2011) The Return of the Wage Phillips Curve. Journal of the European Economic Association, 9, 436-461. https://doi.org/10.1111/j.1542-4774.2011.01023.x

[11] Campbell, C.M. (2010) Deriving the Wage-Wage and Price-Price Phillips Curve from a Model with Efficiency Wages and Imperfect Information. Economics Letters, 107, 242-245. https://doi.org/10.1016/j.econlet.2010.01.036

[12] Roberts, J.M. (1995) New Keynesian Economics and the Phillips Curve. Journal of Money, Credit, and Banking, 27, 975-984. https://doi.org/10.2307/2077783

[13] Taylor, J.B. (1979) Staggered Contracts in a Macro Model. American Economic Review, 69, 108-113.

[14] Taylor, J.B. (1980) Output and Price Stability: An International Comparison. Journal of Economic Dynamics and Control, 2, 109-132.

https://doi.org/10.1016/0165-1889(80)90054-8

[15] Calvo, G.A. (1983) Staggered Contracts in a Utility-Maximizing Framework. Journal of Monetary Economics, 12, 383-398. https://doi.org/10.1016/0304-3932(83)90060-0

[16] Rotemberg, J.J. (1982) Sticky Prices in the United States. Journal of Political Economy, 60, 1187-1211. https://doi.org/10.1086/261117

[17] Fuhrer, J. and Moore, G. (1995) Inflation Persistence. Quarterly Journal of Economics, 110, 127-159. https://doi.org/10.2307/2118513

[18] Ball, L. (1994) Credible Disinflation with Staggered Price-Setting. American Eco- 
nomic Review, 84, 282-289.

[19] Galí, J. and Gertler, M. (1999) Inflation Dynamics: A Structural Econometric Analysis. Journal of Monetary Economics, 44, 195-222. https://doi.org/10.1016/S0304-3932(99)00023-9

[20] Mankiw, N.G. and Ricardo, R. (2002) Sticky Information versus Sticky Prices: A Proposal to Replace the New Keynesian Phillips Curve. Quarterly Journal of Economics, 117, 1295-1328. https://doi.org/10.1162/003355302320935034

[21] Bewley, T.F. (1999) Why Wages Don't Fall During a Recession. Harvard University Press, Cambridge.

[22] Campbell, C.M. (2006) A Model of the Determinants of Effort. Economic Modelling, 23, 215-237. https://doi.org/10.1016/j.econmod.2005.09.006

[23] Shapiro, C. and Stiglitz, J.E. (1984) Equilibrium Unemployment as a Worker Discipline Device. American Economic Review, 74, 433-444.

[24] Akerlof, G.A. (1982) Labor Contracts as Partial Gift Exchange. Quarterly Journal of Economics, 97, 543-569. https://doi.org/10.2307/1885099

[25] Akerlof, G.A. (1984) Gift Exchange and Efficiency Wage Theory: Four Views. American Economic Review, 74, 79-83.

[26] Stiglitz, J.E. (1974) Alternative Theories of Wage Determination and Unemployment in L.D.C.'s: The Labor Turnover Model. Quarterly Journal of Economics, 88, 194-227. https://doi.org/10.2307/1883069

[27] Schlicht, E. (1978) Labor Turnover, Wage Structure and Natural Unemployment. Zeitschrift für die Gesamte Staatswissewnschaft, 134, 337-346.

[28] Salop, S.C. (1979) A Model of the Natural Rate of Unemployment. American Economic Review, 69, 117-125.

[29] Weiss, A. (1980) Job Queues and Layoffs in Labor Markets with Flexible Wages. Journal of Political Economy, 88, 526-538. https://doi.org/10.1086/260884

[30] Roberts, J.M., (1998) Inflation Expectations and the Transmission of Monetary Policy. Federal Reserve Board of Governors.

[31] Pfajfar, D. and Santoro, E. (2010) Heterogeneity, Learning and Information Stickiness in Inflation Expectations. Journal of Economic Behavior and Organization, 75, 426-444. https://doi.org/10.1016/j.jebo.2010.05.012

[32] Levine, P., Pearlman, J., Perendia, G. and Yang, B. (2012) Endogenous Persistence in an Estimated DSGE Model under Imperfect Information. Economic Journal, 122, 1287-1312. https://doi.org/10.1111/j.1468-0297.2012.02524.x

[33] Campbell, C.M. (2014) The Formation of Wage Expectations in the Effort and Quit Decisions of Workers. Economic Modelling, 42, 313-322. https://doi.org/10.1016/j.econmod.2014.07.002

[34] Campbell, C.M. (2009) An Efficiency Wage-Imperfect Information Model of the Aggregate Supply Curve. Working Paper, Northern Illinois University, DeKalb.

[35] Campbell, C.M. (2008) An Efficiency Wage Approach to Reconciling the Wage Curve and the Phillips Curve. Labour Economics, 15, 1388-1415. https://doi.org/10.1016/j.labeco.2008.01.002

[36] Solow, R.M. (1979) Another Possible Source of Wage Stickiness. Journal of Macroeconomics, 1, 79-82. https://doi.org/10.1016/0164-0704(79)90022-3

[37] Liu, Z. and Phaneuf, L. (2007) Technology Shocks and Labor Market Dynamics: Some Evidence and Theory. Journal of Monetary Economics, 54, 2534-2553. https://doi.org/10.1016/j.jmoneco.2007.06.015

[38] Huang, K.X.D., Liu, Z. and Phaneuf, L. (2004) Why Does the Cyclical Behavior of 
Real Wages Change Over Time? American Economic Review, 94, 836-856. https://doi.org/10.1257/0002828042002552

[39] Perry, G.L. (1978) Slowing the Wage-Price Spiral: The Macroeconomic View. Brookings Papers on Economic Activity, 1978, 259-299.

https://doi.org/10.2307/2534266

Submit or recommend next manuscript to SCIRP and we will provide best service for you:

Accepting pre-submission inquiries through Email, Facebook, LinkedIn, Twitter, etc. A wide selection of journals (inclusive of 9 subjects, more than 200 journals)

Providing 24-hour high-quality service

User-friendly online submission system

Fair and swift peer-review system

Efficient typesetting and proofreading procedure

Display of the result of downloads and visits, as well as the number of cited articles Maximum dissemination of your research work

Submit your manuscript at: http://papersubmission.scirp.org/

Or contact jss@scirp.org 